\title{
Studi dan Kajian Ekonomis Pengembangan Pelabuhan Niaga Kabupaten Rembang Propinsi Jawa Tengah
}

\author{
Sukobar, S. Kamilia Aziz, Triaswati MN. \\ Program Studi Diploma Teknik Sipil FTSP ITS, Surabaya \\ Email: kobarabiyi@gmail.com
}

\begin{abstract}
Law no. 22 of 1999 on regional autonomy and wide have been aware of the importance of local government evocative explore and develop the potential of the area has not been explored to the fullest. Commercial port development plan is an effort to accelerate the pace of economic growth and prosperity for the community of Rembang and surrounding areas. The position of the District is between 1110.00 Rembang'- 1110.30' E and 60.30'- 70.60' LS is flanked by two major ports, the Port of Tanjung Emas Semarang and Surabaya Port of Tanjung Perak, causing the position of the Port of Rembang be quite strategis.Untuk determine its feasibility, then the compiled in this study in a port development plan with phasing the short term (2008-2020), medium term (Year 2021 to 2030) and long term (Year 2031 to 2038). To assess the economic feasibility of the indicators used Benefit Cost Ratio (B / C Ratio), Internal Rate of Return (IRR) and Pay Back Period (PBP). Based on the analysis of the growth / projection goods flow, boats, investment income and expenses during the period 2008 to the year 2038 the result that a positive $N P V(N P V>0)$, the value of $B / C=1.014(B / C>1)$, the value of $I R R=12.2951 \%(I R R>I=12 \%)$, investment or payback period Payback Period of 11 years or by 2019. From the results of these calculations are financially Port Development Commercial District Rembang feasible to execute.
\end{abstract}

Keywords: port, investment,worthy.

\section{Abstrak}

Undang-undang No. 22 tahun 1999 tentang otonomi daerah yang luas telah menyadarkan dan menggugah pemerintah daerah akan pentingnya menggali dan mengembangkan potensi daerah yang selama ini belum tergali secara maksimal. Rencana pengembangan Pelabuhan Niaga merupakan salah satu upaya yang dapat mempercepat laju pertumbuhan ekonomi dan kesejahteraan untuk masyarakat Kabupaten Rembang dan sekitarnya. Posisi Kabupaten Rembang berada di antara $111^{0} .00^{\prime}-111^{0} .30$ ' BT dan $6^{0} .30^{\prime}-7^{0} .60^{\prime}$ LS yang diapit oleh dua pelabuhan besar, yaitu Pelabuhan Tanjung Emas Semarang dan Pelabuhan Tanjung Perak Surabaya, menyebabkan posisi Pelabuhan Rembang menjadi cukup strategis. Untuk mengetahui kelayakannya,maka dalam studi ini di susun sebuah rencana pengembangan pelabuhan dengan pentahapan jangka awal (Tahun 2008-2020), jangka menengah (Tahun 2021-2030) dan jangka akhir (Tahun 2031-2038). Untuk menilai kelayakan secara ekonomi dipergunakan indikator Benefit Cost Ratio (B/C Ratio), Internal Rate of Return (IRR) dan Pay Back Period (PBP). Berdasarkan analisa pertumbuhan/proyeksi arus barang, arus kapal, pendapatan dan biaya investasi selama periode tahun 2008 sampai tahun 2038 diperoleh hasil bahwa nilai NPV positif $(\mathrm{NPV}>0)$, nilai $\mathrm{B} / \mathrm{C}=1,014(\mathrm{~B} / \mathrm{C}>1)$, nilai $\mathrm{IRR}=12,2951 \%$ (IRR $>\mathrm{I}=12 \%)$, jangka waktu pengembalian investasi atau Pay Back Period selama 11 tahun atau pada tahun 2019. Dari hasil perhitungan tersebut secara financial Pengembangan Pelabuhan Niaga di Kabupaten Rembang layak untuk di laksanakan.

Kata kunci: pelabuhan, investasi, layak.

\section{Pendahuluan}

Undang-undang No. 22 tahun 1999 tentang Otonomi Daerah yang luas telah menyadarkan pada pemerintah daerah betapa rentannya strategi pembangunan yang hanya mengandalkan pada bantuan pemerintah pusat. Hal ini menggugah pemerintah daerah akan pentingnya menggali dan mengembangkan potensi daerah yang selama ini belum tergali secara maksimal. Rencana Pengembangan Pelabuhan Niaga merupakan salah satu upaya yang dapat meningkatkan potensi Kabupaten 
Rembang sehingga diharapkan dapat mempercepat laju pertumbuhan ekonomi dan kesejahteraan untuk masyarakat Kabupaten Rembang dan sekitarnya. Posisi Kabupaten Rembang berada di antara $111^{0} .00^{\prime}-111^{0} .30^{\prime}$ BT dan $6^{0} .30^{\prime}-7^{0} .60^{\prime}$ LS seperti terlihat pada gambar 1 yang diapit oleh dua pelabuhan besar, yaitu Pelabuhan Tanjung Emas Semarang dan Pelabuhan
Tanjung Perak Surabaya, menyebabkan posisi rencana Pelabuhan Rembang menjadi cukup strategis.

Dalam studi ini akan dilakukan pengumpulan data primer maupun data sekunder sebagai bahan kajian untuk rencana pengembangan Pelabuhan niaga Rembang sampai dengan tahun 2038 (26 tahun dari sekarang).

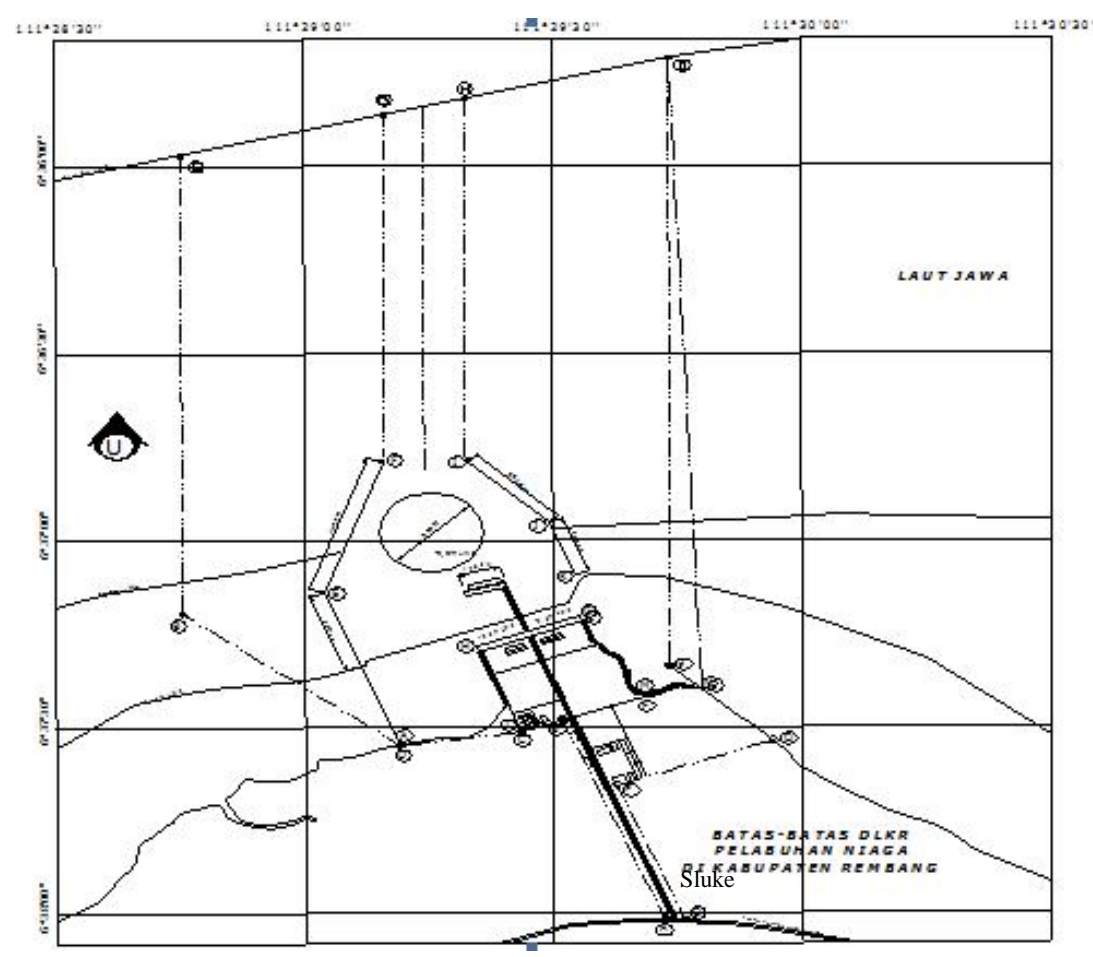

Gambar 1. Layout pelabuhan

\subsection{Peramalan Arus Barang dan Arus Kapal}

Berdasarkan pengamatan data pada tahun-tahun sebelumnya, maka perkembangan arus barang dan arus kapal menunjukkan tren meningkat linier, sehingga proyeksi arus barang dan arus kapal menggunakan metode Trend Linier;

$\mathrm{Y}=\mathrm{a}+\mathrm{bx}$

Dimana:

$$
\mathrm{a}=\sum \mathrm{y}: \mathrm{n}
$$

$$
\begin{aligned}
\mathrm{b}= & \sum \mathrm{xy}: \sum \mathrm{x}^{2} \\
& \text { jika } \sum \mathrm{x}=0
\end{aligned}
$$

$\mathrm{y}=$ variabel permintaan

$\mathrm{n}=$ jumlah data

$\mathrm{x}=$ variabel tahun

\subsection{Analisa Aliran Kas}

a. Metode Nilai Sekarang (P)

$$
P(i)=\sum_{t=0}^{N} \frac{A_{t}}{(1+i)^{t}}
$$

atau 
$P(i)=\sum_{t=0}^{N} A_{t,}(P / F, i \%, t)$

Dimana:

$\mathrm{P}(\mathrm{i})=$ nilai sekarang dari keseluruhan aliran kas pada tingkat bunga $\mathrm{i} \%$

$\mathrm{A}_{\mathrm{t}}=$ alliran kas pada akhir periode $\mathrm{t}$

$\mathrm{i}=$ MARR

$\mathrm{N}=$ horizon perencanaan (periode)

b. Analisa Periode Pengembalian (Payback Period)

$O=-P+\sum_{t=1}^{N \prime} A t(P / F, i \%, t)$

Dimana $\mathrm{A}_{\mathrm{t}}$ adalah aliran kas yang terjadi pada periode $\mathrm{t}$ dan $\mathrm{N}$ ' adalah periode pengembalian yang akan dihitung. Apabila At sama dari satu periode ke periode yang lain (deret seragam) maka dapat dinyatakan berdasarkan faktor P/A sebagai berikut:

$O=-P+\sum_{i=1}^{N \prime} A t(P / A, i \%, t)$

c. Perhitungan Rate of Return (ROR)

$$
N P W=\sum_{t=0}^{N} F_{t}\left(1+i^{*}\right)^{-t}=0
$$

Dimana:

$\mathrm{NPW}=$ net present worth

$\mathrm{F}_{\mathrm{t}} \quad=$ aliran kas pada periode $\mathrm{t}$

$\mathrm{N}=$ umur proyek atau periode studi dari proyek tersebut

$i^{*}=$ nilai ROR dari proyek atau investasi tersebut.

Karena $F_{t}$ pada persamaan bisa bernilai positif maupun negatif maka persamaan ROR dapat juga dinyatakan:
$\mathrm{NPW}=\mathrm{PW}_{\mathrm{R}}-\mathrm{PW}_{\mathrm{E}}=0$

atau

$\sum_{\tau=0}^{N} R_{\mathrm{t}}\left(P / F, i^{*} \%, t\right)-\sum_{\mathrm{\tau}=0}^{N} E_{\mathrm{t}}\left(P / F, i^{*} \%, t\right)=0$

Dimana:

$\mathrm{PW}_{\mathrm{R}}=$ nilai present worth dari semua pemasukan (aliran kas positif)

$\mathrm{PW}_{\mathrm{E}}=$ nilai present worth dari semua pengeluaran (aliran kas negatif)

$\mathrm{R}_{\mathrm{t}} \quad=$ penerimaan netto yang terjadi pada periode ke-t

$\mathrm{E}_{\mathrm{t}} \quad=$ pengeluaran netto yang terjadi pada periode ke-t, termasuk investasi awal $(\mathrm{P})$

\section{Metodologi}

\subsection{Pengumpulan data}

Untuk tujuan dimaksud pada pendahuluan tersebut, tentunya membutuhkan peramalan-peramalan guna mendapatkan nilai proyeksi besarnya arus muatan barang dan arus kapal. Dalam memperhitungkan arus muatan barang dan kapal didasarkan pada pertumbuhan arus muatan barang di daerah hinterland yang potensial melalui Pelabuhan Rembang yang selama ini melalui pelabuhan lain seperti Pelabuhan Tanjung Emas Semarang dan Pelabuhan Tanjung Perak Surabaya.

\subsection{Penilaian kelayakan secara ekonomis}

Untuk menilai kelayakan secara ekonomis dipergunakan indicator:

- Benefit Cost Ratio (B/C Ratio)

Perhitungan Benefit Cost Ratio diperlukan untuk mengetahui kelayakan 
suatu pelabuhan layak dikembangkan atau tidak, ditinjau dari segi ekonomisnya. Jika nilai rasio biaya manfaat yang didapat lebih besar dari satu maka pengembangan ini layak untuk dilaksanakan.

\section{- Internal Rate of Return (IRR)}

Internal Rate of Return adalah suatu kondisi suku bunga dimana akan menghasilkan nilai sekarang yang seimbang (sama) antara biaya dan manfaat selama umur rencana.

\section{- Pay Back Period (PBP)}

Pay Back Period menunjukkan periode waktu yang diperoleh untuk menutup kembali uang yang telah diinvestasikan dengan hasil yang akan diperoleh atau (Net Cash Flow) dari investasi tersebut, hal ini diperlukan untuk menentukan waktu yang dibutuhkan untuk dapat mengembalikan modal awal yang telah diinvestasikan bagi pengembangan ini, maka dalam studi ini disusun sebuah rencana pengembangan pelabuhan dengan pentahapan-pentahapan sebagai berikut:

- Jangka Awal (tahun 2008-2020)

- Jangka Menengah (tahun 2021-2030)

- Jangka Akhir (tahun 2031 - 2038)

\subsection{Identifikasi Kondisi Teknis}

Berdasarkan hasil survey teknis di lokasi rencana, didapatkan bahwa sifat pasang surut di perairan Rembang adalah pasang surut campuran dengan dominasi semi diurnal, yang berarti selama kurang lebih 24 jam terjadi 2 kali pasang dan 2 kali surut dengan tinggi rata-rata pasang surut adalah 0,89 m. Sedangkan kecepatan arus pada saat pasang maupun pada saat surut adalah $0-0,3 \mathrm{~m} / \mathrm{det}$. Gelombang di lokasi rencana pelabuhan mempunyai ketinggian bervariasi antara 0,1-1,5 meter, dengan dominasi $0,1-0,6$ meter.

\section{Hasil dan Pembahasan}

\subsection{Proyeksi Arus Barang}

Proyeksi arus barang di Pelabuhan Rembang dilakukan perhitungan dengan mempertimbangkan peninjauan proyeksi pertumbuhan ekonomi di hinterland dan trend pertumbuhan kegiatan di pelabuhan (data arus barang yang dikirim ke Jawa Tengah bagian Timur dan Jawa Timur bagian Barat, melewati Pelabuhan Tanjung Emas Semarang dan Pelabuhan Tanjung Perak Surabaya). Proyeksi arus barang dari tahun 2006 sampai dengan 2038 digambarkan pada tabel 1 .

Pada Tabel 1. menunjukkan hasil perhitungan pertumbuhan dan perkiraan arus barang non kemasan maupun kemasan yang melalui Pelabuhan Rembang dari kawasan hinterland.

\subsection{Analisa Pertumbuhan dan Peramalan Arus Kapal}

Proyeksi arus kunjungan kapal ke Pelabuhan Rembang dihitung dengan mempertimbangkan proyeksi pertumbuhan ekonomi di hinterland pelabuhan dan rata-rata pertumbuhan kegiatan di pelabuhan (dari data arus barang yang masuk). Proyeksi arus kapal sampai dengan tahun 2038 digambarkan pada tabel 2 . 


\section{ISSN.1907-753X}

Tabel 1. Proyeksi Arus Barang Pelabuhan Rembang Tahun 2006-2038

\begin{tabular}{|c|c|c|c|c|c|c|}
\hline \multirow{2}{*}{ Tahun ke } & \multirow{2}{*}{ Tahun } & \multicolumn{3}{|c|}{ Arus Barang } & \multicolumn{2}{|c|}{ Arus Peti Kemas } \\
\hline & & ton & $\mathrm{m}^{3}$ & ton/lt & boks & TEU's \\
\hline 1 & 2006 & 839124 & 620,246 & $1,079,182$ & 5,175 & 8,279 \\
\hline 2 & 2007 & 883100 & 676,857 & 637,997 & 5,588 & 8,940 \\
\hline 3 & 2008 & 929380 & 738,635 & 675,947 & 6,034 & 9,654 \\
\hline 4 & 2009 & 978086 & 806,051 & 716,154 & 6,516 & 10,424 \\
\hline 5 & 2010 & 1029345 & 879,621 & 758,753 & 7,036 & 11,256 \\
\hline 6 & 2011 & 1083289 & 959,905 & 803,886 & 7,598 & 12,155 \\
\hline 7 & 2012 & 1140061 & $1,047,517$ & 851,703 & 8,204 & 13,125 \\
\hline 8 & 2013 & 1199808 & $1,143,126$ & 902,365 & 8,859 & 14,173 \\
\hline 9 & 2014 & 1262686 & $1,247,461$ & 956,040 & 9,567 & 15,304 \\
\hline 10 & 2015 & 1328860 & $1,361,318$ & $1,012,908$ & 10,331 & 16,526 \\
\hline 11 & 2016 & 1398501 & $1,485,568$ & $1,073,158$ & 11,156 & 17,845 \\
\hline 12 & 2017 & 1471792 & $1,621,158$ & $1,136,992$ & 12,046 & 19,270 \\
\hline 13 & 2018 & 1548924 & $1,769,124$ & $1,204,624$ & 13,008 & 20,808 \\
\hline 14 & 2019 & 1630099 & $1,930,595$ & $1,276,278$ & 14,047 & 22,469 \\
\hline 15 & 2020 & 1715527 & $2,106,803$ & $1,352,194$ & 15,168 & 24,263 \\
\hline 16 & 2021 & 1805432 & $2,299,095$ & $1,432,627$ & 16,379 & 26,200 \\
\hline 17 & 2022 & 1900049 & $2,508,937$ & $1,517,843$ & 17,687 & 28,291 \\
\hline 18 & 2023 & 1999625 & $2,737,931$ & $1,608,128$ & 19,100 & 30,550 \\
\hline 19 & 2024 & 2104419 & $2,987,827$ & $1,703,784$ & 20,625 & 32,988 \\
\hline 20 & 2025 & 2214705 & $3,260,530$ & $1,805,130$ & 22,271 & 35,622 \\
\hline 21 & 2026 & 2330771 & $3,558,124$ & $1,912,504$ & 24,050 & 38,465 \\
\hline 22 & 2027 & 2452919 & $3,882,880$ & $2,026,265$ & 25,970 & 41,536 \\
\hline 23 & 2028 & 2581469 & $4,237,277$ & $2,146,793$ & 28,043 & 44,852 \\
\hline 24 & 2029 & 2716756 & $4,624,020$ & $2,274,490$ & 30,282 & 48,532 \\
\hline 25 & 2030 & 2859132 & $5,046,062$ & $1,409,782$ & 32,700 & 52,298 \\
\hline 26 & 2031 & 3008971 & $5,506,624$ & $2,553,123$ & 35,311 & 56,473 \\
\hline 27 & 2032 & 3166661 & $6,009,222$ & $2,704,989$ & 38,131 & 60,982 \\
\hline 28 & 2033 & 3332616 & $6,557,693$ & $2,865,889$ & 41,175 & 65,850 \\
\hline 29 & 2034 & 3507268 & $7,156,225$ & $3,036,360$ & 44,463 & 71,106 \\
\hline 30 & 2035 & 3691073 & $7,809,385$ & $3,216,971$ & 48,013 & 76,782 \\
\hline 31 & 2036 & 3884511 & $8,522,160$ & $3,408,325$ & 51,847 & 82,912 \\
\hline 32 & 2037 & 4088086 & $9,299,991$ & $3,611,061$ & 55,986 & 89,530 \\
\hline 33 & 2038 & 4302329 & $10,148,816$ & $3,825,857$ & 60,457 & 96,677 \\
\hline
\end{tabular}

\subsection{Proyeksi Pendapatan Pelabuhan}

Prakiraan pendapatan pelabuhan Rembang sampai dengan tahun 2038, diperoleh dari jasa pelabuhan, stevedoring, gudang, labuh, tambat, dan lain-lain. Hal tersebut digambarkan pada tabel 3. Proyeksi biaya operasi dan investasi pelabuhan Rembang dapat dilihat pada tabel 4 dan 5 (investasi fisik. Maintenance, pengerukan, pegawai, dan lain-lain). Perhitungan $\mathrm{NPV}, \mathrm{B} / \mathrm{C}$, dan pay back periode dapat dilihat pada tabel 6, sedangkan perhitungan IRR dapat dilihat pada tabel 7.

\section{Simpulan}

Dari analisa data, maka didapatkan hasil perhitungan kelayakan financial sebagai berikut:

1. $\mathrm{NPV}=0,032$ positif $(\mathrm{NPV}>0)$

2. $\mathrm{B} / \mathrm{C}=1,014(\mathrm{~B} / \mathrm{C}>1)$

3. $\mathrm{IRR}=12,2951 \%(\mathrm{IRR}>\mathrm{I}=12 \%)$ 
Jangka waktu pengembalian investasi atau Pay Back Period adalah selama 11 tahun atau pada tahun 2019.

Dari hasil perhitungan tersebut, maka secara financial pengembangan

Pelabuhan Niaga di Kabupaten

Rembang layak untuk dilaksanakan.

\section{Daftar Pustaka}

Pujawan, I Nyoman. 1995. Ekonomi Teknik. Jakarta: PT.Guna Widya.

Suad Husnan, Suwarsono. 1994. Studi Kelayakan Proyek. Yogyakarta: UPP AMP YKPN.

Soedjono Kramadibrata. 2002.

Perencanaan Pelabuhan. Bandung: Penerbit ITB

Tabel 2. Proyeksi Arus Kapal Pelabuhan

Rembang Tahun 2006-2038

\begin{tabular}{|c|c|c|c|}
\hline \multirow{2}{*}{ Tahun ke } & \multirow{2}{*}{ Tahun } & \multicolumn{2}{|c|}{ Satuan } \\
\hline & & Unit & GT \\
\hline 1 & 2006 & 117 & 997,647 \\
\hline 2 & 2007 & 120 & $1,018,210$ \\
\hline 3 & 2008 & 122 & $1,039,196$ \\
\hline 4 & 2009 & 125 & $1,060,615$ \\
\hline 5 & 2010 & 127 & $1,082,475$ \\
\hline 6 & 2011 & 130 & $1,104,786$ \\
\hline 7 & 2012 & 133 & $1,127,556$ \\
\hline 8 & 2013 & 135 & $1,150,796$ \\
\hline 9 & 2014 & 138 & $1,174,515$ \\
\hline 10 & 2015 & 141 & $1,198,723$ \\
\hline 11 & 2016 & 144 & $1,223,430$ \\
\hline 12 & 2017 & 147 & $1,248,648$ \\
\hline 13 & 2018 & 150 & $1,274,382$ \\
\hline 14 & 2019 & 153 & $1,300,648$ \\
\hline 15 & 2020 & 156 & $1,327,456$ \\
\hline 16 & 2021 & 159 & $1,354,816$ \\
\hline 17 & 2022 & 163 & $1,382,740$ \\
\hline 18 & 2023 & 166 & $1,411,239$ \\
\hline 19 & 2024 & 169 & $1,440,326$ \\
\hline 20 & 2025 & 173 & $1,470,013$ \\
\hline 21 & 2026 & 177 & $1,500,311$ \\
\hline 22 & 2027 & 180 & $1,531,234$ \\
\hline 23 & 2028 & 184 & $1,562,794$ \\
\hline 24 & 2029 & 188 & $1,595,005$ \\
\hline 25 & 2030 & 192 & $1,627,879$ \\
\hline 26 & 2031 & 195 & $1,661,431$ \\
\hline 27 & 2032 & 199 & $1,695,675$ \\
\hline 28 & 2033 & 204 & $1,730,624$ \\
\hline 29 & 2034 & 208 & $1,766,294$ \\
\hline 30 & 2035 & 212 & $1,802,699$ \\
\hline 31 & 2036 & 216 & $1,839,854$ \\
\hline 32 & 2037 & 221 & $1,877,776$ \\
\hline 33 & 2038 & 225 & $1,916,478$ \\
\hline
\end{tabular}


Jurnal APLIKASI ISSN.1907-753X

Tabel 3. Proyeksi Pendapatan Pelabuhan Rembang

\begin{tabular}{|c|c|c|c|c|c|}
\hline \multirow{3}{*}{$\begin{array}{c}\text { Tahun } \\
\text { ke }\end{array}$} & \multirow{3}{*}{ Tahun } & \multicolumn{3}{|c|}{ PENDAPATAN } & \multirow{3}{*}{ JUMLAH } \\
\hline & & 1 & 2 & 3 & \\
\hline & & Pelayanan Kapal & Pelayanan Barang & Rupa-rupa Usaha & \\
\hline 0 & 2008 & & & & 0 \\
\hline 1 & 2009 & $254,853,227.97$ & $1,227,992,556.37$ & $29,374,714.11$ & $1,512,220,498.45$ \\
\hline 2 & 2010 & $260,105,990.73$ & $1,298,158,123.48$ & $31,372,000.44$ & $1,589,636,114.65$ \\
\hline 3 & 2011 & $265,467,017.82$ & $1,372,464,773.57$ & $33,508,321.62$ & $1,671,440,113.01$ \\
\hline 4 & 2012 & $270,938,540.69$ & $1,451,166,569.97$ & $35,793,425.02$ & $1,757,898,535.68$ \\
\hline 5 & 2013 & $276,522,836.74$ & $1,534,533,848.29$ & $38,237,742.81$ & $1,849,294,427.84$ \\
\hline 6 & 2014 & $282,222,230.35$ & $1,622,854,305.36$ & $40,852,440.11$ & $1,945,928,975.82$ \\
\hline 7 & 2015 & $288,039,093.77$ & $1,716,434,164.09$ & $43,649,466.50$ & $2,048,122,724.36$ \\
\hline 8 & 2016 & $293,975,848.18$ & $1,815,599,419.74$ & $46,641,611.16$ & $2,156,216,879.08$ \\
\hline 9 & 2017 & $300,034,964.63$ & $1,920,697,173.46$ & $49,842,561.91$ & $2,270,574,700.00$ \\
\hline 10 & 2018 & $306,218,965.12$ & $2,032,097,059.50$ & $53,266,968.39$ & $2,391,582,993.01$ \\
\hline 11 & 2019 & $312,530,423.63$ & $2,150,192,771.84$ & $56,930,509.66$ & $2,519,653,705.13$ \\
\hline 12 & 2020 & $318,971,967.19$ & $2,275,403,704.53$ & $60,849,966.58$ & $2,655,225,638.30$ \\
\hline 13 & 2021 & $325,546,276.97$ & $2,408,176,692.69$ & $65,043,299.25$ & $2,798,766,268.91$ \\
\hline 14 & 2022 & $332,256,089.40$ & $2,548,987,897.49$ & $69,529,729.96$ & $2,950,773,716.85$ \\
\hline 15 & 2023 & $339,104,197.33$ & $2,698,344,809.32$ & $74,329,831.89$ & $3,111,778,838.54$ \\
\hline 16 & 2024 & $346,093,451.16$ & $2,856,788,399.79$ & $79,465,624.09$ & $3,282,347,475.04$ \\
\hline 17 & 2025 & $353,226,760.02$ & $3,024,895,426.14$ & $84,960,673.14$ & $3,463,082,859.30$ \\
\hline 18 & 2026 & $360,507,093.03$ & $3,203,280,900.31$ & $90,840,201.93$ & $3,654,628,195.27$ \\
\hline 19 & 2027 & $357,937,480.50$ & $3,392,600,734.75$ & $97,131,206.16$ & $3,847,669,421.41$ \\
\hline 20 & 2028 & $375,521,015.18$ & $3,593,554,578.17$ & $103,862,578.92$ & $4,072,938,172.27$ \\
\hline 21 & 2029 & $383,260,853.59$ & $3,806,888,855.10$ & $111,065,244.12$ & $4,301,214,952.81$ \\
\hline 22 & 2030 & $391,160,217.29$ & $4,033,400,024.46$ & $118,772,299.27$ & $4,543,332,541.02$ \\
\hline 23 & 2031 & $399,222,394.24$ & $4,273,938,073.34$ & $127,019,168.29$ & $4,800,179,635.87$ \\
\hline 24 & 2032 & $407,450,740.18$ & $4,529,410,263.46$ & $135,843,765.11$ & $5,072,704,768.75$ \\
\hline 25 & 2033 & $415,848,680.00$ & $4,800,785,149.18$ & $145,286,668.68$ & $5,361,920,497.86$ \\
\hline 26 & 2034 & $424,419,709.20$ & $5,089,096,887.15$ & $155,391,310.40$ & $5,668,907,906.75$ \\
\hline 27 & 2035 & $433,167,395.30$ & $5,395,449,859.51$ & $166,204,174.66$ & $5,994,821,429.47$ \\
\hline 28 & 2036 & $442,095,379.38$ & $5,721,023,634.01$ & $177,775,013.45$ & $6,340,894,026.84$ \\
\hline 29 & 2037 & $451,207,377.53$ & $6,067,078,286.22$ & $190,157,076.17$ & $6,708,442,739.92$ \\
\hline 30 & 2038 & $460,507,182.47$ & $6,343,960,111.00$ & $203,407,355.52$ & $7,007,874,648.99$ \\
\hline
\end{tabular}

Tabel 4. Proyeksi Biaya Operasi Pelabuhan Rembang

\begin{tabular}{|c|c|c|c|c|c|c|c|c|}
\hline \multirow{3}{*}{$\begin{array}{c}\text { Tahun } \\
\text { ke }\end{array}$} & \multirow{3}{*}{ Tahun } & \multicolumn{7}{|c|}{ Biaya } \\
\hline & & 1 & 2 & 3 & 4 & 5 & 6 & \\
\hline & & Pegawai & $\begin{array}{c}\text { Bahan \& } \\
\text { Operasi }\end{array}$ & Pemeliharaan & Penyusutan & $\begin{array}{c}\text { Administrasi } \\
\text { Kantor }\end{array}$ & Biaya Umum & Jumlah \\
\hline 0 & 2008 & & & & & & & 0 \\
\hline 1 & 2009 & $512,808,925.93$ & $46,360,141.41$ & $67,530,528.60$ & $385,547,500.00$ & $19,790,444.11$ & $57,381,421.74$ & $1,089,418,961.79$ \\
\hline 2 & 2010 & $521,355,741.36$ & $47,519,144.94$ & $69,556,444.46$ & $385,547,500.00$ & $20,126,881.66$ & $58,259,357.49$ & $1,102,365,069.91$ \\
\hline 3 & 2011 & $530,045,003.71$ & $48,707,123.56$ & $71,643,137.79$ & $385,547,500.00$ & $20,469,038.65$ & $59,150,725.66$ & $1,115,562,529.37$ \\
\hline 4 & 2012 & \begin{tabular}{|l}
$538,879,087.11$ \\
\end{tabular} & $49,924,801.65$ & $73,792,431.93$ & $385,547,500.00$ & $20,817,012.30$ & $60,055,731.76$ & $1,129,016,564.75$ \\
\hline 5 & 2013 & $547,860,405.23$ & $51,172,921.70$ & $76,006,204.88$ & $385,547,500.00$ & $21,170,901.51$ & $60,974,584.46$ & $1,142,732,517.78$ \\
\hline 6 & 2014 & $556,991,411.98$ & $52,452,244.74$ & $78,286,391.03$ & $385,547,500.00$ & $21,530,806.84$ & $61,907,495.60$ & $1,156,715,850.19$ \\
\hline 7 & 2015 & $566,274,502.18$ & $53,763,550.86$ & $80,634,982.76$ & $385,547,500.00$ & $21,896,830.55$ & $62,854,680.29$ & $1,170,972,046.64$ \\
\hline 8 & 2016 & $575,712,512.22$ & $55,107,639.63$ & $83,054,032.24$ & $385,547,500.00$ & $22,269,076.67$ & $63,816,356.89$ & $1,185,507,117.65$ \\
\hline 9 & 2017 & $585,307,720.75$ & $56,485,330.62$ & $85,545,653.21$ & $385,547,500.00$ & $22,647,650.98$ & $64,792,747.15$ & $1,200,326,602.71$ \\
\hline 10 & 2018 & $595,062,849.43$ & $57,897,463.00$ & $88,112,022.81$ & $385,547,500.00$ & $23,032,661.04$ & $65,784,076.19$ & $1,215,436,572.47$ \\
\hline 11 & 2019 & $\begin{array}{l}604,980,563.59 \\
\end{array}$ & $59,344,900.48$ & $90,755,383.49$ & $385,547,500.00$ & $23,424,216.28$ & $66,790,572.55$ & $1,230,843,136.39$ \\
\hline 12 & 2020 & $615,063,572.98$ & $60,828,522.99$ & $93,478,045.00$ & $474,557,500.00$ & $23,822,427.96$ & $67,812,468.31$ & $1,335,562,537.24$ \\
\hline 13 & 2021 & $625,314,632.53$ & $62,349,236.07$ & $96,282,386.35$ & $474,557,500.00$ & $24,227,409.23$ & $68,849,999.08$ & $1,351,581,163.26$ \\
\hline 14 & 2022 & $635,736,543.08$ & $63,907,966.97$ & $99,170,857.94$ & $474,557,500.00$ & $24,639,275.19$ & $69,903,404.06$ & $1,367,915,547.24$ \\
\hline 15 & 2023 & $646,332,152.13$ & $65,505,666.14$ & $102,145,983.67$ & $474,557,500.00$ & $25,058,142.87$ & $70,972,926.14$ & $1,384,572,370.95$ \\
\hline 16 & 2024 & $657,104,354.66$ & $67,143,307.80$ & $105,210,363.18$ & $474,557,500.00$ & $25,484,131.30$ & $72,058,811.91$ & $1,401,558,468.85$ \\
\hline 17 & 2025 & $668,056,093.91$ & $68,821,890.49$ & $108,366,674.08$ & $474,557,500.00$ & $25,917,361.53$ & $73,161,311.74$ & $1,418,880,831.75$ \\
\hline 18 & 2026 & $679,190,362.14$ & $70,542,437.75$ & $111,617,674.30$ & $474,557,500.00$ & $26,357,956.67$ & $74,280,679.81$ & $1,436,546,610.67$ \\
\hline 19 & 2027 & $690,510,201.51$ & $72,305,998.70$ & $114,966,204.53$ & $474,557,500.00$ & $26,806,041.94$ & $75,417,174.21$ & $1,454,563,120.89$ \\
\hline 20 & 2028 & $702,018,704.87$ & $74,113,648.67$ & $118,415,190.67$ & $474,557,500.00$ & $27,261,744.65$ & $76,571,056.97$ & $1,472,937,845.83$ \\
\hline 21 & 2029 & $713,719,016.61$ & $75,966,489.88$ & $121,967,646.39$ & $474,557,500.00$ & $27,725,194.31$ & $77,742,594.14$ & $1,491,678,441.33$ \\
\hline 22 & 2030 & $725,614,333.56$ & $77,865,652.13$ & $125,626,675.78$ & $849,557,500.00$ & $28,196,522.61$ & $78,932,055.84$ & $1,885,792,739.92$ \\
\hline 23 & 2031 & $737,707,905.78$ & $79,812,293.43$ & $129,395,476.05$ & $849,557,500.00$ & $28,675,863.50$ & $80,139,716.29$ & $1,905,288,755.05$ \\
\hline 24 & 2032 & $750,003,037.55$ & $81,807,600.77$ & $133,277,340.33$ & $849,557,500.00$ & $29,163,353.18$ & $81,365,853.95$ & $1,925,174,685.78$ \\
\hline 25 & 2033 & $762,503,088.17$ & $83,852,790.79$ & $137,275,660.54$ & $849,557,500.00$ & $29,659,130.18$ & $82,610,751.51$ & $1,945,458,921.19$ \\
\hline 26 & 2034 & $775,211,472.98$ & $85,949,110.56$ & $141,393,930.36$ & $849,557,500.00$ & $30,163,335.39$ & $83,874,696.01$ & $1,966,150,045.30$ \\
\hline 27 & 2035 & $788,131,664.19$ & $88,097,838.32$ & $145,635,748.27$ & $849,557,500.00$ & $30,676,112.10$ & $85,157,978.86$ & $1,987,256,841.74$ \\
\hline 28 & 2036 & $801,267,191.93$ & $90,300,284.28$ & $150,004,820.72$ & $849,557,500.00$ & $31,197,606.00$ & $86,460,895.94$ & $2,008,788,298.87$ \\
\hline 29 & 2037 & $814,621,645.13$ & $92,557,791.39$ & $\begin{array}{l}154,504,965.34 \\
\end{array}$ & $849,557,500.00$ & $31,727,965.30$ & $87,783,747.65$ & $2,030,753,614.81$ \\
\hline 30 & 2038 & $828,198,672.55$ & $94,871,736.17$ & $159,140,114.30$ & $849,557,500.00$ & $32,267,340.71$ & $89,126,838.98$ & $2,053,162,202.71$ \\
\hline
\end{tabular}


Tabel 5. Proyeksi Biaya Investasi Pelabuhan Rembang

\begin{tabular}{|c|c|c|c|c|c|c|c|c|c|c|c|}
\hline \multirow{3}{*}{ No. } & \multirow{3}{*}{\multicolumn{2}{|c|}{ Uraian Pekerjaan }} & \multirow{3}{*}{ Volume Sat } & \multirow{3}{*}{ Harga Satuan } & \multirow{3}{*}{ Jumlah } & \multicolumn{2}{|c|}{$\begin{array}{l}\text { Alternatif Sumber Dana } \\
\end{array}$} & \multicolumn{4}{|c|}{$\begin{array}{l}\text { Thapapan Pembangunan } \\
\end{array}$} \\
\hline & & & & & & \multirow{2}{*}{ Pusat (APBN) } & \multirow{2}{*}{ Daerah (APBD) } & \multicolumn{2}{|c|}{ Tahap I (2008) } & Tahap II (2020) & $\begin{array}{c}\text { Tahap III (2030) } \\
\end{array}$ \\
\hline & & & & & & & & APBN & APBD & $\begin{array}{ll}\text { APBN } & \text { APBD } \\
\end{array}$ & $\begin{array}{ll}\text { APBN } & \text { APBD } \\
\end{array}$ \\
\hline \multirow{2}{*}{\multicolumn{12}{|c|}{$\begin{array}{l}\text { I. Fasilitas Pokok } \\
\text { a. Bangunan }\end{array}$}} \\
\hline a. Bangunan & & & & & & & & & & & \\
\hline & Pengerukan kolam pelabuhan & & $250,000 \mathrm{~m}^{2}$ & 25,000 & $6,250,000,000$ & $\sqrt{1}$ & & $5,250,000,000$ & & & \\
\hline 2 & Pembangunan trestle, Iebar 8m & & $240 \mathrm{~m}^{1}$ & $40,000,000$ & $9,600,000,000$ & $\sqrt{1}$ & & $9,600,000,000$ & & & \\
\hline & $\begin{array}{l}\text { Pembangunan dermaga, lebar } 15 \mathrm{~m} \\
\end{array}$ & & $150 \mathrm{~m}^{1}$ & $112,500,000$ & $16,875,000,000$ & $\sqrt{1}$ & & $16,875,000,000$ & & & \\
\hline & Pembangunan breakwater & & $1,835 \mathrm{~m}^{1}$ & $17,000,000$ & $31,195,000,000$ & $\sqrt{2}$ & & $31,195,000,000$ & & & \\
\hline 5 & Pembangunan gudang penumpukan & & $3,312 \mathrm{~m}^{2}$ & $1,000,000$ & $3,312,000,000$ & & $\sqrt{ }$ & & $1,656,000,000$ & $1,656,000,000$ & \\
\hline \multirow[t]{3}{*}{6} & $\begin{array}{l}\text { Pembangunan lapangan penumpukan } \\
\end{array}$ & & $1,750 \mathrm{~m}^{2}$ & 250,000 & $437,500,000$ & & $\mathrm{v}$ & & $437,500,000$ & & \\
\hline & & Jumlah a & & & $67,669,500,000$ & & & & & & \\
\hline & \multicolumn{11}{|l|}{ b. Instalasi Fasilitas Pelabuhan } \\
\hline & Instalasi Air Kapal & & $490 \mathrm{~m}^{1}$ & 800,000 & $392,000,000$ & & $\sqrt{ }$ & & $392,000,000$ & & \\
\hline 2 & Reservoir kapasitas 25 ton & & 1 unit & $35,000,000$ & $35,000,000$ & & $\sqrt{ }$ & & $35,000,000$ & & \\
\hline \multirow[t]{3}{*}{3} & Instalasi jaringan listrik & & $590 \mathrm{~m}^{1}$ & $2,000,000$ & $1,180,000,0000$ & & $\sqrt{v}$ & & $1,180,000,0000$ & & \\
\hline & 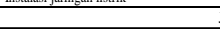 & Jumlahb & mon & & $\begin{array}{l}1,1,607,000,000 \\
\end{array}$ & & & & & & \\
\hline & & Jumlah I & & & $69,276,500,000$ & & & & & & \\
\hline \multicolumn{12}{|c|}{ II. Fasilitas Penunjang } \\
\hline \multicolumn{12}{|c|}{ a. Tanath recumulang } \\
\hline 1 & Pembebasan tanah & & $495,000 \mathrm{~m}^{2}$ & 40,000 & $19,800,000,000$ & $\sqrt{1}$ & & $18,000,000,000$ & $1,800,000,000$ & & \\
\hline \multirow[t]{3}{*}{2} & Pematangan lahan & & $1,125,000 \mathrm{~m}^{2}$ & 30,000 & $33,750,000,000$ & 1 & & & $255,450,000$ & $124,200,000$ & $7,500,000,000$ \\
\hline & & Jumlah a & & & $53,550,000,000$ & & & & & & \\
\hline & \multicolumn{11}{|l|}{ b. Jalan dan bangunan } \\
\hline 1 & Pembangunan jalan akses masuk, lebar 10 & & $1,500 \mathrm{~m}^{1}$ & $3,500,000$ & $5,250,000,000$ & $\frac{1}{2}$ & & $5,250,000,000$ & & & \\
\hline 2 & Pembangunan kantor pelabuhan & & $600 \mathrm{~m}^{2}$ & $1,750,000$ & $1,050,000,000$ & & $\sqrt{2}$ & & $1,050,000,000$ & & \\
\hline \multirow{2}{*}{\multicolumn{2}{|c|}{3 Pembangunan lapangan parkir }} & & $2,050 \mathrm{~m}^{2}$ & 100,000 & $205,000,000$ & & $\sqrt{2}$ & & $205,000,000$ & & \\
\hline & & Jumlah b & & & $6,505,000,000$ & & & & & & \\
\hline c. & Emplasemen & & & & $60,055,000,000$ & & & & & & \\
\hline & Rivetment (slope protection) & & $1,000 \mathrm{~m}^{1}$ & 700,000 & $700,000,000$ & & v & & $700,000,000$ & & \\
\hline & & Jumlah c & & & $700,000,000$ & & & & & & \\
\hline & & Jumlah II & & & $60,755,000,000$ & & & & & & \\
\hline & & & & & $130,031,500,000$ & & & & & & \\
\hline \multicolumn{3}{|c|}{ Biaya Investasi (APBN) } & & & & $122,720,000,000$ & & $87,17,000,000$ & & & \\
\hline & a Investasi (APBD) & & & & & & $7,311,500,000$ & & $7,7,10,950,000$ & $1,780,200,000$ & $\frac{7,500,000,000}{750000000}$ \\
\hline & Biaya Investasi & & & & & & $130,031,500,000$ & & $94,880,950,000$ & $1,780,200,000$ & $7,500,000,000$ \\
\hline
\end{tabular}

Tabel 6. Perhitungan NPV, B/C, dan Pay Back Period

\begin{tabular}{|c|c|c|c|c|c|c|c|c|c|}
\hline & & & Penerimaan & & Pengeluaran & & NPV & $\mathrm{B} / \mathrm{C}$ & PBP \\
\hline $\begin{array}{l}\text { Tahun } \\
\text { ke }\end{array}$ & Tahun & $\begin{array}{c}\mathrm{I}=12,00 \\
\%\end{array}$ & $\begin{array}{l}\text { Pendapatan } \\
\text { (Juta Rp.) }\end{array}$ & $\begin{array}{l}\text { Present } \\
\text { value } \\
\text { (Juta Rp.) }\end{array}$ & $\begin{array}{c}\text { Biaya } \\
\text { (Juta Rp.) }\end{array}$ & $\begin{array}{l}\text { Present } \\
\text { value } \\
\text { (Juta Rp.) }\end{array}$ & $\begin{array}{c}\text { (Net Present } \\
\text { Value) } \\
\text { (Juta Rp.) }\end{array}$ & $\begin{array}{l}\text { (Cost } \\
\text { Benefit } \\
\text { Ratio) }\end{array}$ & $\begin{array}{l}\text { (Pay Back } \\
\text { Period) }\end{array}$ \\
\hline 0 & 2008 & 1.0000 & & & $7,710,950$ & $7,710,950$ & $-7,710,950$ & & $-7,710,950$ \\
\hline 1 & 2009 & 0.8929 & $1,512,220$ & $1,350,197$ & $1,089,419$ & 972,696 & 377,501 & & $-7,288,148$ \\
\hline 2 & 2010 & 0.7972 & $1,589,636$ & $1,267,248$ & $1,102,365$ & 878,799 & 388,449 & & $-6,800,877$ \\
\hline 3 & 2011 & 0.7118 & $1,671,440$ & $1,189,698$ & $1,115,563$ & 794,035 & 395,663 & & $-6,245,000$ \\
\hline 4 & 2012 & 0.6355 & $1,757,899$ & $1,117,176$ & $1,129,017$ & 717,510 & 399,666 & & $-5,616,118$ \\
\hline 5 & 2013 & 0.5674 & $1,849,294$ & $1,049,339$ & $1,142,733$ & 648,417 & 400,922 & & $-4,909,556$ \\
\hline 6 & 2014 & 0.5066 & $1,945,929$ & 985,868 & $1,156,716$ & 586,028 & 399,840 & & $-4,120,343$ \\
\hline 7 & 2015 & 0.4523 & $2,048,123$ & 926,467 & $1,170,972$ & 529,688 & 396,778 & & $-3,243,192$ \\
\hline 8 & 2016 & 0.4039 & $2,156,217$ & 870,860 & $1,185,507$ & 478,806 & 392,053 & & $-2,272,482$ \\
\hline 9 & 2017 & 0.3606 & $2,270,575$ & 818,792 & $1,200,327$ & 432,850 & 385,942 & & $-1,202,234$ \\
\hline 10 & 2018 & 0.3220 & $2,391,583$ & 770,026 & $1,215,437$ & 391,338 & 378,688 & & $-26,088$ \\
\hline 11 & 2019 & 0.2875 & $2,519,654$ & 724,340 & $1,230,843$ & 353,838 & 370,502 & & $1,262,723$ \\
\hline 12 & 2020 & 0.2567 & $2,655,226$ & 681,530 & $3,115,763$ & 799,739 & $-118,208$ & & \\
\hline 13 & 2021 & 0.2292 & $2,798,766$ & 641,405 & $1,351,581$ & 309,748 & 331,657 & & \\
\hline 14 & 2022 & 0.2046 & $2,950,774$ & 603,787 & $1,367,916$ & 279,903 & 323,884 & & \\
\hline 15 & 2023 & 0.1827 & $3,111,779$ & 568,510 & $1,384,572$ & 252,956 & 315,554 & & \\
\hline 16 & 2024 & 0.1631 & $3,282,347$ & 535,422 & $1,401,558$ & 228,625 & 306,797 & & \\
\hline 17 & 2025 & 0.1456 & $3,463,083$ & 504,378 & $1,418,881$ & 206,652 & 297,726 & & \\
\hline 18 & 2026 & 0.1300 & $3,654,628$ & 475,246 & $1,436,547$ & 186,808 & 288,438 & & \\
\hline 19 & 2027 & 0.1161 & $3,857,669$ & 447,902 & $1,454,563$ & 168,885 & 279,017 & & \\
\hline 20 & 2028 & 0.1037 & $4,072,938$ & 422,228 & $1,472,938$ & 152,695 & 269,534 & & \\
\hline 21 & 2029 & 0.0926 & $4,301,215$ & 398,119 & $1,491,678$ & 138,069 & 260,050 & & \\
\hline 22 & 2030 & 0.0826 & $4,543,333$ & 375,472 & $9,385,793$ & 775,665 & $-400,193$ & & \\
\hline 23 & 2031 & 0.0738 & $4,800,180$ & 354,195 & $1,905,289$ & 140,587 & 213,608 & & \\
\hline 24 & 2032 & 0.0059 & $5,072,705$ & 334,200 & $1,925,175$ & 126,835 & 207,366 & & \\
\hline 25 & 2033 & 0.0588 & $5,361,920$ & 315,406 & $1,945,459$ & 114,438 & 200,968 & & \\
\hline 26 & 2034 & 0.0525 & $5,668,908$ & 297,736 & $1,966,150$ & 103,264 & 194,472 & & \\
\hline 27 & 2035 & 0.0469 & $5,994,821$ & 281,119 & $1,987,257$ & 93,190 & 187,929 & & \\
\hline 28 & 2036 & 0.0419 & $6,340,894$ & 265,489 & $2,008,788$ & 84,106 & 181,382 & & \\
\hline 29 & 2037 & 0.0374 & $6,708,443$ & 250,784 & $2,030,754$ & 75,916 & 174,867 & & \\
\hline \multirow[t]{2}{*}{30} & 2038 & 0.0334 & $7,098,875$ & 236,946 & $2,053,162$ & 68,530 & 168,415 & & \\
\hline & & Jumlah & $107,451,073$ & $19,059,886$ & $61,553,670$ & $18,801,566$ & 258,320 & 1,014 & \\
\hline
\end{tabular}


Jurnal APLIKASI

Volume 10, Nomor 1, Pebruari 2012

ISSN.1907-753X

Tabel 7. Perhitungan IRR

\begin{tabular}{|c|c|c|c|c|c|c|c|c|}
\hline $\begin{array}{c}\text { Tahun } \\
\text { ke }\end{array}$ & Tahun & $\begin{array}{c}\mathrm{I}=12,00 \\
\%\end{array}$ & $\begin{array}{l}\text { Penerimaan } \\
\text { Pendapatan } \\
\text { (Juta Rp.) }\end{array}$ & $\begin{array}{l}\text { Present } \\
\text { value } \\
\text { (Juta Rp.) }\end{array}$ & $\begin{array}{c}\text { Pengeluaran } \\
\text { Biaya } \\
\text { (Juta Rp.) }\end{array}$ & $\begin{array}{l}\text { Present } \\
\text { value } \\
\text { (Juta Rp.) }\end{array}$ & $\begin{array}{c}\text { NPV } \\
\text { (Net Present } \\
\text { Value) } \\
\text { (Juta Rp.) }\end{array}$ & $\begin{array}{c}\text { B/C } \\
\text { (Cost Benefit } \\
\text { Ratio) }\end{array}$ \\
\hline 0 & 2008 & 1.0000 & & & $7,710,950.000$ & $7,710.950$ & $-7,710,950.000$ & \\
\hline 1 & 2009 & 0.8905 & $1,512.220$ & $1,346.649$ & $1,089,419.000$ & 970.140 & 376.509 & \\
\hline 2 & 2010 & 0.7930 & $1,589.636$ & $1,260.597$ & $1,102,365.000$ & 874.186 & 386.411 & \\
\hline 3 & 2011 & 0.7062 & $1,671.440$ & $1,180.343$ & $1,115,563.000$ & 787.792 & 392.551 & \\
\hline 4 & 2012 & 0.6289 & $1,757.899$ & $1,105.479$ & $1,129,017.000$ & 709.998 & 395.481 & \\
\hline 5 & 2013 & 0.5600 & $1,849.294$ & $1,035.624$ & $1,142,733.000$ & 639.942 & 395.682 & \\
\hline 6 & 2014 & 0.4987 & $1,945.929$ & 970.425 & $1,156,716.000$ & 576.848 & 393.577 & \\
\hline 7 & 2015 & 0.4441 & $2,048.123$ & 909.558 & $1,170,972.000$ & 520.021 & 389.537 & \\
\hline 8 & 2016 & 0.3955 & $2,156.217$ & 852.719 & $1,185,507.000$ & 468.832 & 383.887 & \\
\hline 9 & 2017 & 0.3522 & $2,270.575$ & 799.629 & $1,200,327.000$ & 422.719 & 376.910 & \\
\hline 10 & 2018 & 0.3136 & $2,391.583$ & 750.028 & $1,215,437.000$ & 381.175 & 368.853 & \\
\hline 11 & 2019 & 0.2793 & $2,519.654$ & 703.675 & $1,230,843.000$ & 343.743 & 359.932 & \\
\hline 12 & 2020 & 0.2487 & $2,655.226$ & 660.346 & $3,115,763.000$ & 774.880 & -114.534 & \\
\hline 13 & 2021 & 0.2215 & $2,798.766$ & 619.835 & $1,351,581.000$ & 299.331 & 320.504 & \\
\hline 14 & 2022 & 0.1972 & $2,950.774$ & 581.949 & $1,367,916.000$ & 269.779 & 312.170 & \\
\hline 15 & 2023 & 0.1756 & $3,111.779$ & 546.508 & $1,384,572.000$ & 243.166 & 303.342 & \\
\hline 16 & 2024 & 0.1564 & $3,282.347$ & 513.348 & $1,401,558.000$ & 219.199 & 294.149 & \\
\hline 17 & 2025 & 0.1393 & $3,463.083$ & 482.313 & $1,418,881.000$ & 197.611 & 284.702 & \\
\hline 18 & 2026 & 0.1240 & $3,654.628$ & 453.261 & $1,436,547.000$ & 178.166 & 275.095 & \\
\hline 21 & 2029 & 0.0876 & $4,301.215$ & 376.716 & $1,491,678.000$ & 130.647 & 246.069 & \\
\hline 22 & 2030 & 0.0780 & $4,543.333$ & 354.354 & $9,385,793.000$ & 732.038 & -377.684 & \\
\hline 23 & 2031 & 0.0695 & $4,800.180$ & 333.395 & $1,905,289.000$ & 132.331 & 201.064 & \\
\hline 24 & 2032 & 0.0619 & $5,072.705$ & 313.747 & $1,925,175.000$ & 119.072 & 194.675 & \\
\hline 25 & 2033 & 0.0551 & $5,361.920$ & 295.325 & $1,945,459.000$ & 107.152 & 188.173 & \\
\hline 26 & 2034 & 0.0490 & $5,668.908$ & 278.047 & $1,966,150.000$ & 96.435 & 181.612 & \\
\hline 27 & 2035 & 0.0437 & $5,994.821$ & 261.839 & $1,987,257.000$ & 86.798 & 175.041 & \\
\hline 28 & 2036 & 0.0389 & $6,340.894$ & 246.631 & $2,008,788.000$ & 78.132 & 168.499 & \\
\hline 29 & 2037 & 0.0346 & $6,708.443$ & 232.358 & $2,030,754.000$ & 70.339 & 162.019 & \\
\hline \multirow[t]{2}{*}{30} & 2038 & 0.0308 & $7,098.875$ & 218.960 & $2,053,162.000$ & 63.328 & 155.632 & \\
\hline & & Jumlah & $107,451.074$ & $18,510.299$ & $61,553,670.000$ & $18,510.270$ & 0.032 & 1.000 \\
\hline
\end{tabular}


Halaman ini sengaja dikosongkan 